\title{
The Construction and Deconstruction of English Catholicism in Spain: Fake News or White Legend?
}

\author{
Berta Cano-Echevarría
}

The Spanish English Lady, one of Miguel de Cervantes' Exemplary Novels (1613), combines fictional and historical characters to tell the love story between a Spanish girl, Isabela, and an Englishman who is secretly Catholic, Ricaredo. The story begins in Spain, in 1596, with the Sack of Cadiz by the English forces where Isabela, still a child, is made hostage and taken to England; it continues in England, where she is kept hidden from the authorities by the family of her captor Clotaldo, until Queen Elizabeth finds out and claims her as her property; and it concludes back in Spain, where the protagonist is able to return to her family and finally reunite with her English fiancé, Clotaldo's son, Ricaredo, after he has proven worthy of her through a series of trials. Critics have long been baffled by Cervantes' positive construction of England, and more specifically of Queen Elizabeth as a mostly benign character; even Clotaldo, who has kidnapped the child, contravening the orders of the Conde de Leste (presumably the Earl of Essex), is not treated as the odious character we might expect. To explain the sympathetic treatment of most of the English characters critics have resorted to focusing on the secret Catholicism of Clotaldo and his family, thus making young Ricaredo a suitable match for the Spanish girl and enabling her to be raised in captivity according to her religion. ${ }^{1}$ But the most persuasive explanation has been to establish the composition of this particular novella to around 1605 , the year when the peace between Spain and England was ratified

1 E.g. Cairns E.C., "Crypto-Catholicism in a Protestant Land: 'La Española Inglesa", Bulletin of the Cervantes Society of America 36, 2 (2016) 127-144; Ricapito J.V., Cervantes' Novelas Ejemplares: Between History and Creativity (West Lafayette: 1996) 34-36. A number of critics believe that Cervantes is obliquely advocating for religious tolerance or ecumenism e.g. cf. Luttikhuizen, F., "Cervantes and International Affairs: A Historical Interpretation of Two Episodes in the 'Novelas ejemplares", Mediterranean Studies 15 (2006) 62-78; Da Costa Fontes M., "Love as an Equalizer in La Española Inglesa", Romance Notes 16, 3 (1975) 742748. For E. Allison Peers the charm of the story derives from the generosity with which the English are portrayed: 'Queen Elizabeth, so recently the Spaniard's bete noire, is idealized to such a degree that one might suppose the author to have been deliberately working for an Anglo-Spanish understanding' (Peers A.E., "Cervantes in England", Bulletin of Spanish Studies 24 (1947) 226-238, here 227). 
following almost twenty years of war between the two countries. ${ }^{2}$ According to this theory Cervantes willingly contributed to the promotion of international friendship by writing this story about an Anglo-Spanish love affair in the romance genre, and may even have been commissioned to write it by those involved in negotiating the treaty. ${ }^{3}$

However this may be, what the early modern Spanish readers encountered in this story was a very mild version of the life of religious dissidents in England. Despite their Catholicism Clotaldo's family is wealthy and admitted to the court; they have to keep their faith a secret but this does not prevent them from arranging a marriage with a Scottish Catholic family for their son, and they only fear detection when the queen summons Isabela to court. At this point Clotaldo dreads becoming a martyr but Isabela reassures him that she will know how to answer for her Catholicism, not telling lies about her upbringing or causing any damage to her adoptive family:

yo confio en el cielo, que me ha de dar palabras en aquel instante, por su divina misericordia, que no solo no os condenen, sino que redunden en provecho vuestro. ${ }^{4}$

[for I trust in the divine goodness and mercy of Heaven, that it will put such words into my mouth as will not only not condemn you, but redound to your advantage.]

Isabela's suggestion of the use of equivocation in case she is asked about religion does not necessarily suggest that Cervantes was particularly well

2 For a discussion of the historicity of Cervantes novella and its connection with the peace $\mathrm{cf}$. Johnson C.B., "La Española Inglesa and the Practice of Literary Production" Viator 19 (1988) 377-416.

3 The dating of the Novelas Exemplares is open to debate as the collection was published in 1613 but the different tales were written throughout an extended period that may have gone as far back as the 159 os. Cf. Rico F., "Sobre la cronología de las novelas de Cervantes", in Pellistrandi B. - Couderc C. coord., 'Por discreto y por amigo': mélanges offerts à Jean Canavaggio (Madrid: 2005) 159-165. Cervantes was in Valladolid when the English embassy arrived in the city to ratify the treaty that had been negotiated and signed the previous year in London, and it has been proposed that he was one of the authors of the anonymous account that chronicled the celebrations that took place in the city. See Marín Cepeda P. (ed.), Relación de lo sucedido en la ciudad de Valladolid desde el punto del felicísimo nacimiento del príncipe Don Felipe (Burgos: 2005) 33-40.

4 Cervantes Saavedra Miguel de, Novelas Exemplares (Madrid: Juan de la Cuesta, 1613) 88. Cervantes Miguel de, The Exemplary Novels by Cervantes, trans. W.K. Kelly (London: William Clowes, 1881) 278-314. 
informed about the pressures Catholics had to face in England. ${ }^{5}$ It may just be a happy coincidence, but the truth is that the doctrine of equivocation that Cervantes seems to be invoking through Isabela was central to the debate over truthfulness and untruthfulness that was at the heart of the religious controversy in England. English Catholics were specifically concerned with these debates as they were forced to demonstrate their loyalty to the crown by attending Protestant services, so they were constantly confronted with the dilemma between protecting their lives and possessions and remaining true to their faith: managing to avoid confessing their religious identity without openly telling a lie became an art, an art Isabela seems able to master. ${ }^{6}$ But how much information did Cervantes have about English Catholics? Did he have any direct sources? And, more importantly, were these available generally to his contemporaries?

Some answers to these questions may lie in the distribution of news about England and the English available in Early Modern Spain during the years of the Anglo-Spanish war, an issue this essay explores through the reading of a number of texts that provided information about English affairs. There was a comparative scarcity of news reports concerning England in Spain. ${ }^{7}$ The reason behind this apparent lack of information is complex and ranges from the poor knowledge of the English tongue to Inquisitorial intervention banning books from outside Spain, more in particular, books from Protestant countries. ${ }^{8}$ I argue, however, that the knowledge, or lack of knowledge, about

5 Equivocation as understood by the Catholic controversialists of the time referred both to ambiguous speech and to mental reservation, so that both forms of utterance or partial utterance could be used without committing the sin of untruthfulness. Cervantes could be familiar with the doctrine of equivocation and mental reservation through a variety of sources. His probable Jewish converse ascendancy and his experience as a captive in Argel had undoubtedly confronted him with the dangers of openly confessing a persecuted faith. Moreover, the work of the Spanish theologian Martín de Azpilicueta Humanae Aures (1584) was one of most fervent apologies of the possibility of reserving a meaning in the mind to avoid the sin of lying in certain situations, and circulated more amply in Spain than those of the English proponents of this practice, who were themselves indebted to Azpilicueta. Cf. Zagorin P., "The Historical Significance of Lying and Dissimulation", Social Research 63, 3 (1996) 863-912.

6 Robert Persons, the head of the English mission in Spain, was one of the main apologists of the lawfulness of this strategy in certain situations. Cf. Carrafiello M.L., "Robert Parsons and Equivocation, 16o6-1610", Catholic Historical Review 79, 4 (1993) 671-68o.

7 By 'comparative' I mean compared with news about Spain in England Cf. Sowerby T., "Elizabethan Diplomatic Networks and the Spread of News", in Raymond J. - Moxham N. (eds.), News Networks in Early Modern Europe (Leiden: 2016) 305-327.

8 Warren A.R., "Inquisitions and Scholarship", Social Science History 39, 4 (2015) 667-702, here $683^{-684}$. 
English affairs derived not so much from a lack of interest, but from a certain political convenience that suited both the Spanish authorities and the English exile community in order to promote an image of England as a primarily Catholic country subjected to a temporary Protestant rule that would necessarily end, an image that very often was based on mis/disinformation. To explore my argument I have chosen texts from three different genres representative of the different channels that delivered information and news in Early Modern Spain: the newsletter, the biographical-hagiographical account and the cordelsheet. Each of these genres had a different formula for delivering supposedly trustworthy information about a topic, and responded to the demands of different sets of audiences. I will be referring to a period $(1588-1605)^{9}$ prior to the development of the periodical press when information about contemporary affairs spread mostly as single events and the channels of international communication were fragile, based primarily on diplomatic correspondence, travellers' accounts and the communication established by the exile community. ${ }^{10}$

Much has been written about the Black Legend and the construction of the Spanish Machiavel, about how the racial difference in skin colour signified or how the fear of an invasion from Spain instigated a fierce anti-Catholic sentiment, but little about how the English were regarded by the Spaniards. ${ }^{11}$ The Black Legend that circulated in England about Spain's evil practices and arrogant character was not publicized in Spain and was not challenged by a

9 From the Armada defeat to the ratification of the Anglo-Spanish peace in Valladolid.

10 Cf. Díaz Noci J., "The Iberian Position in European News Networks: A Methodological Approach", in Raymond J. - Moxham N. (eds.), News Networks in Early Modern Europe (Leiden: 2016); Borreguero Beltrànin C., "Philip of Spain: The Spider's Web of News and Information", in Dooley B. (ed.), The Dissemination of News and the Emergence of Contemporaneity in Early Modern Europe (Farnham: 2010) 23-50. The earliest periodical news publication in the peninsula dates from 1619, and the biggest boom of the press news in Europe can be dated to the second half of the seventeenth century. Earlier, other forms of non-periodical publications contributed to the dissemination of news in Europe and particularly in Spain. Cf. Espejo C., "El primer periódico de la Península Ibérica: la Gazeta de Valencia (1619)", Obra Periodística 2 (2012), and Chartier R. - Espejo C., Comunicación y propaganda en el Barroco. La aparición del periodismo en Europa (Madrid: 2012).

11 The Black Legend about Spain has been an endless topic of debate around the deserved or undeserved cruel image of Spanish Imperialism. Only recently a highly popular and polemical book explaining the Black Legend as a campaign of racist prejudices launched by the northern Protestants towards the Southern Catholics has received an avalanche of critical responses from prominent historians. Cf. Roca Barea E., Imperiofobia y leyenda negra. Roma. Rusia, Estados Unidos y el Imperio Español (Madrid: 2016); and for the opposite view: Villacañas J.L., Imperiofilia y el populismo nacional-católico (Madrid: 2019). For a study on how the Black Legend blends with anti-Catholicism cf. Álvarez-Recio L., Fighting the Anti-Christ: A History of Anti-Catholicism in Tudor England (Brighton: 2011). 
mirror negative image in response. Rather, we can identify a 'White Legend' of sorts, equally based on selected news and partial information but delivering an image with which the Spanish people could identify and empathise. ${ }^{12}$ The image of the English that transpires from the few pieces of information that circulated in Spain represented the common population as composed of primarily secret Catholics at heart who were either persecuted for their ideas or remained silently waiting for their country to return to the path of reconciliation with Rome, a situation that justified Spain's interference with English affairs as a policy of liberation.

If we compare the stereotype of the typical Spaniard in England, which we can find in Black Legend propaganda, with Spain's English stereotype (if indeed there was one), even in the toughest years of the war, we observe an imbalance. Fictional characters such as those presented in Cervantes' novella are few and far between; moreover, they do not seem to be portrayed distinctively as "the other". Don W. Cruickshank carried out a systematic analysis of the English characters that appear in Golden Age Spanish drama and arrived at the conclusion that:

What all these Spanish plays have in common is a lack of caricature of English people. One can find caricatures of Moors and Frenchmen and other foreigners who "speak funny" in Spanish drama, but not, it seems, English people. If English people are portrayed unfavourably it is not because of their nationality. Spanish dramatists tended to portray the English as no different from themselves, and, when historical facts in the plot obliged them to refer to religious differences, they showed a considerable tolerance. ${ }^{13}$

It could be argued that Spanish theatregoers lacked cultural referents to form for themselves a stereotype to share and ridicule. Even the historical tracts

12 By "White Legend" I refer to the positive image that the Spanish people had of the English as opposed to the negative image of the Spaniards that gave way to the Black Legend. The term "White Legend" has been used previously to refer to historiographical responses to the Black Legend that are criticized for going too far in the "whitening" of the practices used by the Spanish empire by highlighting Spanish altruism and tolerance through a legal system that protected the weak from oppression. Cf. Keen B., "The White Legend Revisited: A Reply to Professor Hanke's 'Modest Proposal', The Hispanic American Historical Review 51, 2 (1971) 336-355.

13 Cruickshank D.W., "Lisping and Wearing Strange Suits: English Characters on the Spanish Stage and Spanish Characters on the English Stage, 1580-1680", in Fothergill-Payne L. and P. (eds.), Parallel Lives: Spanish and English National Drama 1580-1680 (London Toronto: 1991) 203. 
that had framed in narrative form the events that had driven the English to a schism with Rome such as Pedro de Ribadeneyra's Historia Ecclesiastica del scisma del Reyno de Inglaterra (1588) or Gonzalo de Illescas' Historia Pontifical (1573) were censored to remove some of the most critical passages about the behaviour of English monarchs. ${ }^{14}$

The absence of overt criticism is the more intriguing if we take into account that the English nation was one of the most powerful national enemies that the Spaniards had to confront in this period. It is common wisdom that to "know your enemy' is one of the principles of a successful war strategy. However, there seems to have been a certain carelessness about keeping the English under close surveillance. Whereas in England (despite the loathing) there was a sincere interest in learning the Spanish tongue and translating and adapting all sorts of documents, from literary works to travel narratives, Spaniards made no effort to learn the language of the enemy. ${ }^{15}$ Even ambassadors who spent long periods in the country relied heavily on language secretaries. ${ }^{16}$ Thus, the bulk of texts in Spanish that either translated original English documents or transmitted news about England were written by English nationals who knew Spanish. Most of these texts were produced by English Catholic exiles who established themselves temporarily in the colleges of the Iberian Peninsula, with the purpose of returning to their country to proselytise in favour of a reconversion to the old faith. ${ }^{17}$ This small and unified group of translators had a clear

14 In Illesca's Historia Pontifical explicit references to the dishonesty and doubtful chastity of Queen Elizabeth I had to be erased; whereas in Ribadeneyra's Historia Ecclesiastica of 1588 , coinciding with the failed Armada expedition, some attacks against Elizabeth were allowed to be printed, but the $159^{2}$ edition that contained the edict against seminary priests and its consequences to Catholics was sequestered by direct order of Philip II. See Burguillo J., "Pedro de Ribadeneyra y la inestabilidad del discurso histórico literario en torno a la empresa de Inglaterra", in Montes D. - Lillo V. - Vega M.J. (eds.), Saberes Inestables: Estudios sobre expurgación y censura en la España de los siglos XVI y XVII (Madrid: 2018) 174-200. In Calderón de la Barca's play Historia de la Cisma de Ingalaterra, based on Ribadeneyra's Historia Ecclesiastica, even though the plot is centred on Henry viII and Anne Boleyn's affair and ends with Mary Tudor's coronation, Elizabeth is not even mentioned, thus avoiding such thorny issue.

15 For a study on the literary appropriations from Spanish sources by English writers, see Fuchs B., The Poetics of Piracy: Emulating Spain in English Literature (Philadelphia: 2013).

16 The notorious Spanish ambassador Don Diego Sarmiento de Acuña, Count of Gondomar, spent long years in England but there is lack of proof that he was fluent in English. Francis Fowler is known to have been his interpreter and secretary for most of his embassy. Cf. Loomie A.J., "Francis Fowler II, English Secretary of the Spanish Embassy, 16o9-1619", Recusant History 12, 1 (1973) 70-78.

17 On the dearth of translations from English into Spanish cf. Santoyo J.C., "Bibliografía tentativa de traducciones inglés-español, 1577-180o", Bells 1 (199o) 161-187 and CanoEchevarría B., "Sidney Scribbled: The Mysterious Case of Deffensa de la Poesia", Viator 46, 
agenda of what the Spanish readers needed to know about England and they were the first filter of information and textual transmission.

\section{$1 \quad$ Letters from England}

The English colleges established in Valladolid (1589), Seville (1593) and Madrid (1610) were the main centres of reception for correspondence from England apart from the court, and Joseph Creswell, successor to Robert Persons as head of the English mission in Spanish territory, was the recipient and supervisor of much of it:

The Jesuite Creswell hath so good intelligence that their waggeth not a strawe in the Inglishe court but he heareth of it [...] this Creswell hath weekly a porter's burden of letters of intelligence from all places which is the cause of his estimation in this land..$^{18}$

Not all of this correspondence remained in manuscript. Some of the letters were purportedly translated and printed so that Spaniards would learn about the reports sent by English Catholics to their families or friends in exile. The printed letter in early modern Spanish culture can be considered a genre in its own right, and English exiles used it as a way to colour with verisimilitude and intimacy the news that came from England. Some of the most important pamphlets about the English mission take the epistolary format as their model. These 'printed single events newsletters', as Henry Ettinghaussen calls them, were one of the most common ways of reporting news between countries and became 'an international phenomenon, based on - and doubtless further developing - Europe-wide news networks, long before the birth of the periodical press.' ${ }^{19}$ Their personal tone suggested there was an exclusive transmission of information from one correspondent to another, but when they were printed

2 (2015) 357-374. Ernesto Oyarbide believes that Gondomar's knowledge of English was patchy at best. He was able to read some texts but there is no proof that he could hold conversations in English and he constantly used his secretaries of letters as translators. I am grateful to Ernesto Oyarbide for allowing me to read his article "Collecting 'Toute l'Angleterre': English Books, Soft Power and Spanish Diplomacy at the Casa del Sol (16131622)" before its publication in Helmers H. - Cumby J. (eds.), Print and Power in Early Modern Europe (forthcoming).

18 Loomie A.J., The Spanish Elizabethans (New York: 1963) 194-195.

19 Ettinghausen H., "International Relations: Spanish, Italian, French, English and German Printed Single Event Newsletters Prior to Renaudot's Gazette", in Raymond J. - Moxham N. (eds.), News Networks in Early Modern Europe (Leiden - Boston: 2016) 261-279, here 262. 
this exclusivity was lost in favour of a broader audience that was now able to glimpse apparently eye-witnessed documentary evidence about a given event. Thus we have printed letters with information about the situation of the English nuns in exile, ${ }^{20}$ the circumstances of the early years of the English College at Valladolid, ${ }^{21}$ the death of Luisa de Carvajal in London, ${ }^{22}$ and the martyrdoms of Catholic priests on English soil. ${ }^{23}$ All this material, originally in English and in manuscript form, went through a process of selection, translation and editing - probably under the supervision of Joseph Creswell himself until it was ready to reach Spanish readers.

The implicit and explicit claim to truth of these letters does not mean, of course, that they were not embellished or carefully edited to serve the purpose for which they were designed, though this is difficult to ascertain because the original letter seldom survives. One of the most remarkable examples of the use of the epistolary form to construct a powerful narrative for domestic consumption is an exchange of letters between a father and son, the latter studying to become a priest at one of the Spanish Seminaries. ${ }^{24}$ This Carta, whose title could be rendered into English as Letter from a Gentleman in England written to his eldest son, who is in one of the seminaries and had faltered in his purpose to become a priest, is all the more interesting because it is followed by two letters in which the son responds to his father, thus establishing a dialogue that serves as a bridge between the two countries, moving the story forwards and advancing, as it were, the plot.

The printed text gives little information about the circumstances surrounding this exchange. For reasons of confidentiality the names of the protagonists

20 Sander Elizabeth, Traslado de una carta de cierta monia inglesa llamada Isabel Sandera [...] escrita en Ruan ciudad de Francia a Francisco Englefild, Cavallero Ingles residente en Madrid, en que le da cuenta de las persecuciones, y trabajos, que a pasado por nuestra Santa Fe en Inglaterra (Sevilla, Clemente Hidalgo: n.d.).

21 Eclesal Tomas, Relacion de un Sacerdote Ingles, escrita a Flandes a un cauallero de su tierra, desterrado por ser Catolico: en la qual le da cuenta de la venida de su Majestad a Valladolid, y al Colegio de los Ingleses, $y$ lo que alli se hizo en su recebimiento. Traducida de Ingles en Castellano por Tomas Eclesal cauallero ingles (Madrid, Pedro Madrigal: 1592).

22 Peralta Francisco de, Copia de una carta que el padre Francisco de Peralta de la Compañia de Jesus, rector del colegio de los Ingleses de Sevilla, escrivio al padre Rodrigo de Cabredo [...] en que da cuenta de la dichosa muerte que tuvo en Londres la santa señora doña Luysa de Carvajal (s.l.: 1614).

23 Anon., Carta embiada De Londres de vn Religioso Catholico, a otro de España, delos ocho de Nouiembre De 1611. Recebida a 25. de Enero de 1612 en que da noticia de lo que passa a cerca de la persecucion de Los Catholicos en dicho Reyno (Barcelona, Sebastian de Cormellas: 1612).

24 A. - N.N., Carta de un Cavallero de Inglaterra, escrita a su hijo Mayorazgo, que esta en uno de los Seminarios, y avia blandeado en su proposito de ser Sacerdote (n.p.: 16o2). 
are not given, the father signs as A. and the son as N.N.; ${ }^{25}$ nor do we know the identity of the college (Valladolid or Seville), or the whereabouts in England of the family home. We do have, however, some precise dates in the letters. The first is dated 24 August 1602, though we read that it did not reach the College until the 20 November, 'con un mensajero propio' [with a private courier]; ${ }^{26}$ the second was written five days later; and the third, the last response from the son to the father, is dated 6 December of the same year. The fact that we do not have the first letter in the exchange, that of the son presumably announcing his decision to leave the College, opens up all sorts of questions. What were the reasons alleged by the student for his decision? Homesickness? Lack of vocation? The rigours of College life? And - most significantly - why was this letter not included in the printed sequence?

The letter written by the father opens expressing love towards his son and praising his early religious vocation, but soon moves on to declare that now that trust has been broken his sentiments have changed to shame and misery. He believes his son has been tricked by the devil who wants him back into the world to enjoy the material possessions of the family and throw him into eternal condemnation. His decision will also crush the expectations of the younger brother who is about to follow his sibling's example in joining the mission abroad, and of the sister who has always learnt from her brother's advice in his letters home; and as for the rest of the brothers, 'que ponen su contento en seguir al mundo, dellos no hago caso' [who content themselves with following the world, them I ignore]. ${ }^{27}$ To heighten the drama the despair of the mother on hearing the news of her son's return is vividly portrayed, 'sus oraciones, sus ruegos, sus lagrimas' [her prayers, her suplications, her tears]. ${ }^{28}$ And so, since the son has decided to abandon his post at the College and leave a vacancy, the father is willing to travel to Spain and replace him there rather than wait for him to come back. In a highly rhetorical passage, the father imagines his son's soul devoured by wolves:

Es possible que esta es la ropa manchada de mi hijo, muerto por aquel sangriento salteador de almas, el Demonio? Es esta la ropa tan adornada en otro tiempo de ricas joyas, y recamada de todo genero de virtudes, que esta agora teñida y affeada con cuaxarones de sangre del desseo y sed

25 The acronym 'N.' was used in Spain as a cipher for someone whose name is unknown or intends to remain anonymous.

26 A. - N.N., Carta de un Cavallero 1. My translation, here and elsewhere for this text.

27 Ibidem 3.

28 Ibidem 5 . 
de cosas perecederas, de descuydo, de tibieça, de floxedad? Ay de mi, y quien la ha assi afeado? Que lobo carnicero ha tragado a mi hijo, y dexado su vestidura teñida desta manera? ${ }^{29}$

[Is it possible that these should be the stained garments of my child, killed by that bloody thief of souls, the devil? Are these the garments that in other times were adorned with rich jewels and embroidered with all sorts of virtues, now tainted and spoilt with clots of blood from desire and thirst of temporary goods, with indolence, with indifference, with laxity? Woe on me! And who has thus disgraced him? What butcherly wolf has devoured my son and has left his garments tainted in this way?]

The son's response is feeble and brief, but expresses his determination to return. He can only reassure his father that despite his determination he remains a Catholic and a despiser of heresy, his only defence being that when he decided to become a priest he was too young to know his true vocation. However, this letter is followed by a longer one in which he declares that he retracts from his decision: 'he vencido al Enemigo, que me hazia guerra' [I have defeated the Enemy that was at war with me $]^{30}$ and in a similar rhetorical vein (occasionally using the third person) he explains that it all has been but a dream and a trial by God to test his fortitude. He ends up expressing gratitude to his father and to the fathers in the College for helping him see the dangers to his soul repenting his momentary weakness.

What are we to make of this epistolary exchange? Clearly it would be a mistake to take it at face value. What sort of pressures were behind this sudden alteration in the student? Indeed, can we even be sure that this father and son composed their respective letters? And what kind of interventions took place in the process of translation? There seems to be a similarity between the letter of the father and the second letter of the son in that both are highly rhetorical and full of rich, figurative language, which helps avoid references to specific circumstances regarding the student and the College life. It is tempting to consider this exchange as a complete fiction, possibly a book of instruction for the collegians, who could take it as a model of both behaviour and epistolary style, and indeed this might have been the textual origin of the translation. ${ }^{31}$ But the

29 Ibidem 3.

30 Ibidem 7 .

31 The existence of a very similar exchange between a father in England and a son studying in a college in Spain was published a few years later, also in Spanish. In this exchange, however, the father's intentions are to convince his son to desert his faith while the son remains resolved. Cf. N.N. - A.A., Carta, escrita a uno de los colegiales Ingleses que residen 
fact that it is in Spanish points to a rather different kind of target audience. The readers of this book were Spaniards interested in the circumstances of life in the English Colleges and the progress of the mission; some of them may have been donors or would-be donors in support of the whole enterprise, so it was important that they believed in the truthfulness of the account, but would also understand that their generosity was bearing fruit. Such an interpretation is encouraged in the colophon:

Por estas cartas, en parte, se puede ver lo que pretende Dios nuestro Señor, con los trabajos que permite en Inglaterra, pues por ello han venido los seglares a cobrar la estima que aquí se vee de la Dignidad Sacerdotal. ${ }^{32}$

[These letters show, in part, what God our Lord intends with the struggles that he allows to happen in England, because due to them laymen have come to obtain the esteem that is shown here, that of priestly honour.]

Taken in a broader sense this exchange of letters could ultimately be taken by Spanish readers as an allegory of English religious strife, the father representing 'the old religion' and the son standing for the temporary loss of spiritual direction that currently afflicted England as a nation. At the end, due to the firmness and advice of his father the son returns to the right course, as England would undoubtedly reconcile itself to the Church of Rome.

\section{$2 \quad$ Misunderstood Martyrdom}

The higher purpose of the mission in England lies behind many of the halftruths about England that circulated in Spain. Propaganda, however, was not the aim of all distortions of truth. Andrew Hadfield discusses how in this period telling lies had a different kind of resonance than it would receive in later historical periods, partly because of the strain suffered by the victims of religious persecution who put their lives at risk. ${ }^{33}$ Individual self-conscience had to confront social, economic and often legal pressures so that a virtuous balance was sometimes impossible to maintain. Hadfield argues that at

en Madrid, por su padre, para apartarle de su resolucion de ser sacerdote, Traduzida en nuestra lengua. [Signed: N.N.] (La respuesta del hijo a su padre. [Signed: A.A.] (Barcelona, s.n.: 1611)).

32 A. - N.N., Carta de un Cavallero 9.

33 Hadfield A., Lying in Early Modern English Culture: From the Oath of Supremacy to the Oath of Allegiance (Oxford: 2017). 
a time when the need for untruthfulness could be anticipated because of the contradictions imposed on the individual 'there is always a simple response to set beside the complicated one, the two frequently intermingled, overlapping and even confused' ${ }^{34}$ The language produced under these circumstances was double edged and could often be interpreted in more than one way; this double-entendre sometimes became the only escape route for victims of religious suspicions.

Not telling the truth was a sin under any circumstances, but lying could be the only way available to preserve one's life or even those of your own community and therefore it became the responsibility of religious groups, such as the Jesuits, to instruct their followers on how to act when forced to choose between two evils. The most famous pamphlet that the Jesuits circulated secretly among the Catholic community was a manuscript written by Henry Garnet (who would later be executed for his alleged participation in the Gunpowder Plot) which clearly announced in its title how deception was to be embraced in special circumstances: $A$ Treatise of Equivocation wherein is largely discussed the question whether a Catholicke or any other person before a magistrate beying demaunded upon his oath whether a Prieste were in such a place, may (notwithstanding his perfect knowledge to the contrary) without Perjury and securely in conscience answere No, with this secreat meaning reserued in his mynde, That he was not there so that any man is bounde to detect it. ${ }^{35}$ Of course, this pragmatic position was attacked by Protestants, who accused the Jesuits of sophistry and duplicity, while at the same time attacking them for wanting to become martyrs. ${ }^{36}$

In Spain news of the ordeals Catholics had to endure if they remained on or re-entered English soil were among the most sought-after stories concerning England. Among them, one stands out as the best known and most widely circulated of the martyrs' accounts in Spanish. Historia de la vida y martyrio que padecio en Inglaterra, este año de 1595 el P. Henrique Valpolo, was written by Henry Walpole's Jesuit colleague and correspondent, Fr. Joseph Creswell. ${ }^{37}$

34 Ibidem 29.

35 For a discussion on the significance of the treatise in the polemics over equivocation $\mathrm{cf}$. Malloch A., "Father Henry Garnet's Treatise of Equivocation", Recusant History 15, 3 (1980) 387-395. Both Garnet and Persons (above) partly derived their arguments from Martín de Azpilicueta. Cf. Zagorin, "The Historical Significance" 895-897.

36 John Donne attacked this option in Pseudo Martyr (1610) where he accuses the Jesuits of casuistry while at the same time using it himself. Donne J. - Sypher F. J. Pseudo-Martyr [...] A Facsimile Reproduction with an Introduction by Francis Jacques Sypher (New York: 1974).

37 Creswell Joseph, Historia de la vida y martyrio que padecio en Inglaterra, este año de 1595 el P. Henrique Valpolo, sacerdote de la Compañia de Iesus q fue embiado del Colegio de los Ingleses de Valladolid, y ha sido el primer martyr de los Seminarios de España: con el 
Walpole's martyrdom and its textual footprint are particularly revealing of the complexities that were faced by the witnesses of the very crude experiences that surrounded the whole process of martyrdom. Providing testimony of such ordeals was understood as the natural outcome of the mission and it was important that the people involved in the transmission were trustworthy and well informed; however, not everything could be under control when dealing with human reactions to suffering and fear. The experiences of Walpole in England and their rendering in Spanish for the benefit of Catholic readers is a very good example of the sharp edges these stories could expose and the necessity to cover them with forgetfulness or misrepresentation. The documents that have survived provide us with two contradictory versions of Walpole's last year, the first version is the one contained in the original transcriptions of Walpole's depositions of his interrogations after he was taken prisoner. These were reproduced in two obscure publications of the late nineteenth and early twentieth centuries: Augustus Jessopp's One Generation of a Norfolk House (1879), ${ }^{38}$ and John Hungerford Pollen's Unpublished Documents Relating to the English Martyrs (1908). ${ }^{39}$ The other version is the one rendered by Joseph Creswell in Spanish, of which different contemporary copies have survived as well as a translation into French, but no extant copy in English. ${ }^{40}$ This was the only account that reached contemporary readers.

The reason for the popularity of Historia de la Vida has to do with the fact that Walpole was the first martyr produced by the Spanish seminaries and therefore he was taken as a symbol of the seed that the Spanish mission was planting. Even though his stay in Spain was not for very long, his contribution to the consolidation of the Colleges was significant. He participated in the establishment of the new seminary in Seville, where he arrived in December

martyrio de otros quatro sacerdotes los dos de la misma Compañia, y los otros dos de los Seminarios (Madrid: Pedro Madrigal, 1596).

38 Jessopp A., One Generation of a Norfolk House: A Contribution to Elizabethan History (London: 1879).

39 Pollen J.H., Unpublished Documents Relating to the English Martyrs, 2 vols. (London: 1908-1919).

40 Richard Verstegan expressed in a letter the convenience of printing Robert Southwell and Henry Walpole's martyrdom in Spanish "and afterwards they may be put together in Latin with others the like, and in the meantime, it would mean much to be in the vulgar tongue". This opens up the possibility that copies of Creswell's account in Latin and English might have existed, but Jessop was only able to find one translation into French in the Noviciate at Tronchiennes licenced at Arras in 1596. Jessopp A., One Generation 169170. Many English Catholic pamphlets have not survived because their owners destroyed or burned them for fear of incrimination. This may explain the loss of the English copies of Walpole's martyrdom pamphlet. 
1593, just a month after its foundation and in time for the consecration of its chapel, and shortly afterwards he was sent to Valladolid as vice-rector. However, he stayed there only a couple of months before Robert Persons, the head of the Colleges in Spain, deemed him unsuitable for the job and considered moving him back to Seville or to Lisbon (where another new College was starting) as a confessor. This would have certainly been a demotion, but finally the decision was taken that he would be most useful if he returned to England. ${ }^{41}$ Returning to their homeland was in fact the purpose of all the students of the Spanish Colleges; indeed, they had to pledge to do so in an oath they took when admitted. ${ }^{42}$ Even so, Henry Walpole's seniority - he had been at the Colleges of Reims and Rome, he had served as a priest with the regiments of Flanders, he belonged to a wealthy family and had mastered several languages - put him in a special position. Persons must have pondered thoroughly his decision and considered that in sending Walpole to England he was demonstrating how much the colleges were willing to sacrifice. Before Walpole left for England he had an audience with King Philip II, from whom he received a commission and monies to establish yet a new College in France, this one specifically designed for younger children who would receive their first instruction there to be later sent to the Spanish or Roman seminaries for further instruction. ${ }^{43}$

Thus, it was that Walpole sailed from Bilbao to Calais in the late summer of 1594, from whence he travelled to St Omer in Northern France to make the preliminary arrangements for the new institution. Once the first part of his mission was over he was delayed longer than expected by bad weather and the plague that was raging in England but finally he managed to embark on a ship in December in the company of two soldiers of fortune, one of them, his own brother, Thomas. They were disembarked north of the river Humber, at Flamborough Head, and just a few hours later they were apprehended by Lord Huntingdon's men and taken to the village of Kilham for their first cross-examination. ${ }^{44}$ Here commenced a series of interrogations and tortures that have been difficult to express by his biographers. Jessopp, who portrays the history of the Walpole family over a period of fifty years in his engaging

\footnotetext{
41 Jessopp A., One Generation 182-184.

42 For the text of the oath in its different forms Cf. Williams M.E., St Alban's College Valladolid: Four Centuries of English Catholic Presence in Spain (London - New York: 1986) 243-244.

43 Creswell, Historia de la vida.

44 The Earl of Huntingdon was Lord President of the Council in the North and became a relentless persecutor of Catholics in the area of York. Margaret Clitherow is perhaps his most renowned victim. See Lake, P. - Questier, M., The Trials of Margaret Clitherow: Persecution, Martyrdom and the Politics of Sanctity in Elizabethan England (London - New York: 2011).
} 
One Generation of a Norfolk House, refers to the autographed document of Walpole's confession under torture with extreme tactfulness:

Alas! It is a painful document; painful, i.e., to those who would wish to find a man who had endured so much exhibit more heroism than in this case can be claimed for him. But who of us can estimate the power which immeasurable bodily pain must exercise upon a highly sensitive and nervous temperament? ${ }^{45}$

Similarly, Pollen, in his Unpublished Documents Relating to the English Martyrs, which was published as an addition to his renowned earlier work, Acts of the English Martyrs (1891), introduces the hitherto unprinted transcriptions of Walpole's examinations and autographed confession with these words:

The confessions of Father Walpole are more ample than those of any other of our Martyrs, and though they begin admirably, they end sadly. Though they are upon the whole extremely clear, their conclusion is somewhat mysterious, both to the extent of the future Martyr's waverings, and also as to the reason for his instability. ${ }^{46}$

What can be read in these transcriptions published by Pollen of the examinations carried out by the torturer Richard Topcliffe and his associates, first in York prison and later at the Tower of London, is the gradual destruction of human resistance. In his first deposition, Walpole managed to keep most of the information to himself, and though he recognised having met Philip II and some senior, well-known Catholics on the continent, he refused to incriminate other people and expressly denied giving the names of the students who had taken refuge in the Colleges. However, the torments in the Tower must have destroyed his resolve, and after three 'examinationes', in which he confesses little, by the month of June he starts giving important information. The quantity of names he reveals both from abroad and in England, is staggering: this includes the names of all the students in the colleges and their families, informants abroad, people undercover in England, houses that were used as lodging for priests, and various collaborators in strategic positions. Since he was captured almost as soon as he landed, it is perplexing how many names of people and places he was able to provide, so much so that it should not be discounted that some of these names may have been suggested to him by his interrogators.

45 Jessopp, One Generation 261.

46 Pollen, Unpublished Documents 244-245. 
This confession did not stop at names; he embraced the rule of the queen and the new religion and even offered to preach it. In an autographed document he writes:

I never allowed of the ambition of the Popes or any of their unjust usurpation over princes and their kingdoms, and do think hostilitye or invasion of the Spanyard would preiudice both the commonwealth and the catholike religion; and therfore as a true Englishman and subiect to her $\mathrm{Ma}^{\text {tie }}$, and denizen of this realme I would in desire and all endeavour and prayer concurr in the defence and conseruation of my countrye, conforming myselfe to the lawes of the realme, whether I live or dy [...] so not refusing to go to the church, and if I were worthy as others be (I being very meane in learning) there preach only such doctrine as my conscience doth tell me and the spirite of God to be manifestly deduced out of the word of God. ${ }^{47}$

Despite all these confessions, however, following further detention at the Tower he was taken back to York for his trial and execution on 7 April 1595 .

As could be expected, none of these features in Joseph Creswell's Historia de la Vida y Martyrio, which instead presents exemplary behaviour in every aspect of Walpole's life, both as a Jesuit on the continent, and following his capture. The hagiographic, idealized status of the text is hidden behind the semblance of reliability: more than half of it is composed of supposedly transcribed letters, some written by Walpole himself and addressed to Creswell, and yet others addressed to the rector of the college at Valladolid, to Robert Persons, Henry Garnet, or even the Earl of Huntingdon, who was responsible for Walpole's capture and imprisonment at York. How Creswell had access to some of this material is left unexplained. This is not to say that Creswell was inventing everything: indeed, when a collation can be made between one of his transcriptions and an existing manuscript of the original letter we see that in some passages he was rendering a mostly faithful text. ${ }^{48}$ But his attitude to his material was (unsurprisingly) far from objective. One of the recurring tropes that carries the narrative is Walpole's constant desire to become a martyr. He had been present at the trial and execution of Thomas Campion and,

$47 \quad$ Ibidem 266.

48 It is possible to compare an original letter from 13 November transcribed in Pollen Unpublished documents 224-225 and Creswell's rendering of the same letter in Historia de la vida $10-11$. 
according to Creswell, witnessing Campion's martyrdom was instrumental in his conversion to Catholicism:

Hallandose Henrique Valpolo en las disputas que el padre Campiano tuvo con los herejes, y en su muerte, y aviendo escrito la historia de todo lo que en aquel glorioso martyrio passo, aprendio otro camino y espiritu de pelear con herejes, no con armas de hierro ni valentia corporal, sino con la fuerça y eficacia de la palabra de Dios: y assi se determinò de dexar a Inglaterra, y entrar en la misma religion del padre Campiano. ${ }^{49}$

[Being Henry Walpole present in the disputes father Campion had with the heretics, and in his death, and having written the history of everything that happened in such glorious martyrdom, he learnt a different path and spirit of fighting against heretics, not with iron arms or bodily courage, but with the strength and efficacy of the word of God: and so he determined to leave England and profess the same religion as father Campion.]

And just before embarking for England he expresses his hope of not dying at sea 'sino en tierra colgado de una horca de Inglaterra, por amor y servicio de IesuChristo' [but on land, hanging from the gallows in England for the love and service of Jesus Christ]. ${ }^{50}$ This illustrates how the example from previous martyrs could bring new resolutions of sacrifice. But even more than Walpole's attitude towards self-sacrifice what could make the book most useful as a conduct guide for future martyrs is the part devoted to his response to questioning under torture. In a letter included in Creswell's account Walpole recounts his torture and interrogation in York prison reproducing the 'bloody question' and his answer to it (or perhaps Creswell's embellished version) which, according to convention, is expressed in hypothetical terms. ${ }^{51}$

49 Creswell, Historia de la vida 4. My translation, here and elsewhere. From the history of Campion's martyrdom written by Henry Walpole only fragments have survived. Cf. Pollen J.H., Acts of English Martyrs Hitherto Unpublished (London: 1891) 41-48.

$5^{\circ}$ Creswell, Historia de la vida 9 .

$51 \quad$ The so-called 'bloody question' or 'bloody questions' were originally put to Edmund Campion in his trial. He seems to have been the first to call it so and, in their formulation, a hypothetical scenario of conflictive political allegiance was proposed to the defendant. See McGrath P., "The Bloody Questions Reconsidered", Recusant History 20, 3 (1991) 305-319. 
Preguntaronme entre otras preguntas, si porventura el Papa se resolviesse de hazer la guerra a Inglaterra, que cosa haría yo? Respondi, que las circunstancias que entonces occurriessen, me darian mas luz, y que en tal caso recorreria a Dios nuestro Señor, y le pediria consejo, y que pensaria bien en el negocio, antes que me metiesse en cosas de guerra. ${ }^{52}$

[They asked me, among other things, if by chance the Pope decided to start a war against England, what would I do? I answered that the circumstances then occurring would illuminate me and that I would turn to God our Lord and ask for advice, and I would think it over before I intervened in things of war.]

The questions put to Walpole as presented in this text are condensed into seven, with their corresponding answers, and in no case does he provide any particular information about the people who helped him, or those he was supposed to meet or were in any way connected with his mission. He never answers with lies, and he refuses to report anything that could endanger Catholics in England. This catalogue of questions and answers that precedes the final denouement of the trial and execution in York is the climax of the book and must have been the most important section for the students of the colleges: both to learn what they could expect if they were captured, and how they should behave. None of the answers given by Walpole exhibits equivocation; he might refuse to give full details, but his information is always truthful. But if there is one equivocator in this story it is Joseph Creswell himself, who surely knew better about his colleague's predicament at the Tower of London and his final confession under torture.

If Robert Persons ever weighed up the risks of losing such an important Jesuit as Father Walpole - plus the danger of his revealing all his valuable contacts and knowledge - against the gains the propaganda of his martyrdom could render the Catholic mission, he might have come to the conclusion that there was a lot to lose but that still the gamble had to be taken. At any rate the impact of the account was considerable. Even though there is no extant version in English the book circulated widely both among the exile population of English Catholics and among Spanish readers who became fascinated by this and similar stories of modern heroes of the faith. ${ }^{53}$ Such was its impact that Luisa de Carvajal y Mendoza decided to abandon Spain and seek out the perils of preaching the Catholic faith in England after

52 Creswell, Historia de la vida 22.

53 Jessop, One Generation 169-170. 
reading Creswell's version of the exemplary life and tragic death of Henry Walpole. The book finishes with a short conclusion that adds four other martyrs who had lost their lives in England at around the same time as Walpole. ${ }^{54}$ This would provide Spanish readers with an impression of a country that, despite the protestant heresy and the brutal persecution of Catholics, was full of adherents to the old faith willing to sacrifice themselves for the sake of the true religion and never to waver in their resolve. It would only be a matter of time before news about the reconversion of the island could be delivered.

\section{3}

\section{Romancing the Peace}

News about English affairs were more in demand when the long period of war between both countries was envisaged as coming to an end after the deaths of Philip II (1598) and Elizabeth I (1603). The embassy of Juan de Tassis, commissioned to congratulate James VI of Scotland as the new King of England, had the more ambitious purpose of promoting a negotiated peace between Spain and England. The report of this mission, which concluded in 1604 with the Treaty of London, was published in Seville in two separate but consecutive pamphlets in which the good will of the new king towards the Spanish ambassador is made explicit. ${ }^{55}$ To conclude the peace treaty, which was negotiated for almost a year, a more prominent courtier was sent to London, Juan Fernández de Velasco, the Constable of Castile, to supervise the final negotiations and the signing of the peace treaty. Another pamphlet reported Castile's embassy with details about the journey, reception, the peace-signing ceremony itself and the celebration with which all was concluded. ${ }^{56}$ However, these publications were primarily concerned with the ceremonial aspect of the reception and did not inform readers of what was at stake in the negotiations. Contrary to what happened in England, where the agreed document was made public

54 Alexander Rawlins, Robert Southwell, William Mason and John Cornelius.

55 Anon., Relacion muy verdadera del recebimiento y fiestas que se le hizieron en Inglaterra a don Iuan de Tassis, Conde de Villamediana, Embaxador [...] del Rey Don Felipe tercero [...] para el nueuo Rey Iacobo de Inglaterra: dase cuenta de la embaxada, y otras cosas muy notables y dignas de saberse. (Sevilla, Bartolome Gomez: 1603) and Anon., La segunda parte de la embaxada de Don Iuan de Tassis, Conde de Villamediana, y Embaxador [...] del Rey Don Felipe tercero [...] para el nueuo Rey Iacobo de Inglaterra: dase cuenta de lo que su Magestad le respondio, y los grandes comedimientos que se le hizieron (Sevilla, Bartolome Gomez: 16o4).

56 Anon., Relacion de la iornada del [...] Condestable de Castilla, a las pazes entre España, y Inglaterra, que se concluyeron y iuraron en Londres por el mes de agosto (Valladolid, Iuan Yniguez: 1604). 
and translated from Latin with its thirty-four articles itemized to demonstrate that there was nothing to hide, the Spanish authorities were careful not to publicize the actual terms of the agreement. ${ }^{57}$

Instead, in Spain a popular means was used to spread more widely the news of the peace in the form of a chapbook or cordel sheet. The cordel sheet was not uncommon in Spain as a way of releasing news of all kinds, from political and state events to religious festivities and natural catastrophes or remarkable events. This form reached a wide audience because in most cases the news (usually delivered in verse) were not intended for private reading but for public recitation in the squares of the towns or villages, usually by professional minstrels whose presence would attract audiences eager to learn the latest news. The verse Relacion de las pazes, attributed on the title page to one Juan de Lelesma [sic], is a romance, a poetic composition connected with the chivalric oral tradition of narrative verse. ${ }^{58}$ In its four hundred and fifty verses it recounts the peace mission of the Constable of Castille in four sections: an untitled introductory stanza, followed by 'Romance de las capitulaciones' [Romance of the terms of the treaty], 'Pregón de la Paz' [Proclamation of the Peace], and 'Romance de como el Rey visitó al Condestable' [Romance of the King's visit to the Constable]. ${ }^{59}$

Surprisingly, this Relacion de las pazes differs from the more formal Relacion de la jornada in that it provides some specific information about the political, economic and religious achievements of the peace that the prose work omits. The levy of the duties imposed on commerce is given relevance, as well as England's agreement to cease its collaboration with the enemies of the Spanish crown; this may have been of interest to the merchant community, who were the foremost beneficiaries of the peace treaty. The author proves to have first-hand knowledge of the embassy, including a number of aspects about the journey, the ceremonies and the reception that are in accordance with the other printed and manuscript sources. In most probability, the text

57 Anon., Articles of Peace, Entercourse, and Commerce, concluded in the names of [...] James [...] King of Great Britain [...] and Philip the third, King of Spaine, \&c. And Albertus and Isabelia Clara Eugenia, Archdukes of Austrice [...] In a Treatie at London the 18. day of August [...] 1604. Translated out of Latine into English (London, Barker: 1605).

58 Sánchez Pérez M., "Panorámica sobre las Relaciones de sucesos en pliegos sueltos poéticos (siglo XVI)", eHumanista 21 (2012) 336-368.

59 Lelesma Juan de, Relacion de las pazes que se han confirmado en la ciudad de Londres, por el mes de Agosto, del año de 1064 [sic] entre España e Inglaterra, con las Capitulaciones hechas entre los Serenissimos Reyes de España e Inglaterra, y Serenissimos Principes y Archiduques de Austria, cuyo poder y comision lleuo y efectuo el Condestable de Castilla, Iuan Fernandes deVelasco [...] compuesta en verso por Iuan de Lelesma [sic] (Málaga n.p.: 1605). 
was commissioned by the Constable of Castile himself to one of the members of his entourage, given its encomiastic nature and the constant references to his persona; indeed, the constable can be recognized as the hero of the romance. Perhaps given the fantastic nature of the genre, the author has no compunction about inventing a number of untruths to satisfy his audience and convince of the successful outcome of the Spanish side in the negotiations. The constable, for example, never entertained the king, it was the other way round, but this gave due prominence to the constable. However, the most remarkable instance of these falsehoods, which also opens the poem, is that the English people have finally returned to Catholicism, abandoning their heretical practices:

$\begin{array}{ll}\begin{array}{l}\text { Alegrese todo el mundo } \\ \text { aya paz, cesse la guerra, }\end{array} & \text { [Let everyone be happy } \\ \text { reciba España consuelo, } & \text { Let peace come and war stop } \\ \text { pues ya vuelve Ingalaterra } & \text { All Spain should be content } \\ \text { a ser amiga del cielo. } & \text { Because England is at last } \\ \text { La fee santa celestial } & \text { A friend of heaven again. } \\ \text { recibe ya sin desden } & \text { Is welcome without disdain } \\ \text { aquel Reyno principal, } & \text { In that principal kingdom } \\ \text { que quiere estimar el bien } & \text { That wants to reward good } \\ \text { por dar fin a todo mal. }{ }^{60} & \text { And put an end to all evil.] }\end{array}$

A number of details adorns this, such as the laws that the author claims James I has passed to ensure the fulfilment of the new devotion, or how, accordingly, the English were ostentatiously displaying all the Catholic ritual previously outlawed:

$\begin{array}{ll}\begin{array}{l}\text { Despues de todo acabado, } \\ \text { manda publicar el Rey }\end{array} & \begin{array}{l}\text { [Once everything finished, } \\ \text { The king ordered the publication } \\ \text { alrededor del Senado }\end{array} \\ \begin{array}{l}\text { All around the Senate } \\ \text { Ofina y santa Ley }\end{array} & \begin{array}{l}\text { Of the divine and saintly law } \\ \text { Of the Crucified Christ. }\end{array} \\ \text { Tambien mando publicar } & \text { He also ordered in an edict } \\ \text { con istancia y santo zelo, } & \text { To reuild immediately } \\ \text { buelvan a reedificar } & \text { And with saintly zeal } \\ \text { los templos que por el suelo } & \text { All the temples that were } \\ \text { mandaron un tiempo echar. } & \text { Destroyed some time ago. }\end{array}$

6o Lelesma, Relacion de las pazes 1. My translation, here and elsewhere. 
Y con gran veneracion

Christiana y solenemente, los santos de devocion con mucha copia de gente, los lleven en procision. Y con luzes encendidas lamparas, hachas y velas, se les ofrezcan las vidas, ${ }^{61}$
And that with great veneration And Christian solemnity The saints of devotion Should be carried multitudinously In a procession. And that with lights, Torches and candles lit. Lives should be offered to them.]

This poetic relacion is exceptional in showing the important investment that the Spanish authorities (at least those involved in the peace signing) put on presenting the treaty as a victorious outcome. By promoting a particular image of England and the English that is consistent with the idea of a Catholic country at heart, only temporarily lost to the Error of Protestantism, the pamphlet reassures its audience about the benefits of the new peace. The fact that this text was addressed to a popular audience but was probably promoted by the Constable of Castile and those close to the government may be taken to demonstrate that the 'white' image of the English people (as opposed to the Spanish Black Legend) was not something that happened by chance or neglect. It suited the foreign policy of the Spanish to perpetuate an amicable perception of their supposed enemies - a perception that would help in the future to stomach the wedding between an English Prince and a Spanish Infanta, and resuscitate the dream of an Anglo-Spanish alliance that had only really lasted for six years, when Philip II was married to Mary Tudor. If, as has been suggested here, Miguel de Cervantes wrote 'The Spanish English Lady' as a commission to promote the peace treaty of $1604-1605$, he was indeed using his fictional characters in a symbolic and 'exemplary' way. ${ }^{62}$ Ricaredo, the Englishman, has been raised as a Catholic but needs to appeal to the Pope to prove himself true, while Isabela suffers humiliation and disfigurement in her English adventure (recalling the Armada disgrace) but expresses no rancour and remains constant to her youthful love until they can be reunited again in Seville. It can be argued that this work of fiction is no more distant from reality than the purported authentic news and reports from England that the Spaniards had access to; at any rate, with the fallout from the Gunpowder Plot in late 1605 the

\footnotetext{
$61 \quad$ Ibidem 4.

62 Cervantes was in Sevilla at the time of the sack of Cadiz and in Valladolid during the visit of the English embassy, so he had first-hand knowledge of the contemporary events that he was fictionalizing.
} 
aspirations for a peaceful alliance remained in the field of wishful thinking. In the famous group portrait representing Spanish, Dutch and English delegates sitting around a table in the Somerset House, a window opens to a garden with a budding branch. The symbolism hidden in this pictorial representation of the peace treaty commissioned by the Spanish glimpses towards the recurrent combination of illusion and delusion that the Spanish texts about England provided at the time.

\section{Bibliography}

\section{Primary Sources}

A. - N.N., Carta de un Cavallero de Inglaterra, escrita a su hijo Mayorazgo, que esta en uno de los Seminarios, y avia blandeado en su proposito de ser Sacerdote (n.p.: 16o2).

Anon., Carta embiada De Londres de vn Religioso Catholico, a otro de España, delos ocho de Nouiembre De 1611. Recebida a 25. de Enero de 1612 en que da noticia de lo que passa a cerca de la persecucion de Los Catholicos en dicho Reyno (Barcelona, Sebastian de Cormellas: 1612).

Anon., Relacion de la iornada del [...] Condestable de Castilla, a las pazes entre España, y Inglaterra, que se concluyeron y iuraron en Londres por el mes de agosto (Valladolid, Iuan Yniguez: 1604).

Anon., Articles of Peace, Entercourse, and Commerce, concluded in the names of [...] James [...] King of Great Britain [...] and Philip the third, King of Spaine, \&c. and Albertus and Isabelia Clara Eugenia, Archdukes of Austrice [...] In a Treatie at London the 18. day of August [...] 1604. Translated out of Latine into English. (London, Barker: 1605).

Anon., Relacion muy verdadera del recebimiento y fiestas que se le hizieron en Inglaterra a don Iuan de Tassis, Conde de Villamediana, Embaxador [...] del Rey Don Felipe tercero [...] para el nueиo Rey Iacobo de Inglaterra: dase cuenta de la embaxada, y otras cosas muy notables y dignas de saberse (Sevilla, Bartolome Gomez: 1603).

Anon., La segunda parte de la embaxada de Don Iuan de Tassis, Conde de Villamediana, y Embaxador [...] del Rey Don Felipe tercero [...] para el nueиo Rey Iacobo de Inglaterra: dase cuenta de lo que su Magestad le respondio, y los grandes comedimientos que se le hizieron (Sevilla, Bartolome Gomez: 1604).

Cervantes Saavedra Miguel de, Novelas Exemplares (Madrid, Juan de la Cuesta: 1613).

Creswell Joseph, Historia de la vida y martyrio que padecio en Inglaterra, este año de 1595 el P. Henrique Valpolo, sacerdote de la Compañia de Iesus q fue embiado del Colegio de los Ingleses de Valladolid, y ha sido el primer martyr de los Seminarios de España: con el martyrio de otros quatro sacerdotes los dos de la misma Compañia, y los otros dos de los Seminarios (Madrid, Pedro Madrigal: 1596). 
Eclesal Tomas, Relacion de un Sacerdote Ingles, escrita a Flandes a un cauallero de su tierra, desterrado por ser Catolico: en la qual le da cuenta de la venida de su Majestad a Valladolid, y al Colegio de los Ingleses, y lo que allí se hizo en su recebimiento. Traducida de Ingles en Castellano por Tomas Eclesal cauallero ingles (Madrid, Pedro Madrigal: 1592).

Lelesma Juan de, Relacion de las pazes que se han confirmado en la ciudad de Londres, por el mes de Agosto, del año de 1064 [sic] entre España e Inglaterra, con las Capitulaciones hechas entre los Serenissimos Reyes de España e Inglaterra, y Serenissimos Principes y Archiduques de Austria, cuyo poder y comision lleuo y efectuo el Condestable de Castilla, Iuan Fernandes deVelasco [...] / compuesta en verso por Iuan de Lelesma [sic] (Málaga, n.p.: 1605).

N.N. - A.A., Carta, Escrita a uno de los colegiales Ingleses que residen en Madrid, por su padre, para apartarle de su resolucion de ser Sacerdote, Traduzida en nuestra lengua. [Signed: N.N.] (La Respuesta Del Hijo a Su Padre. [Signed: A.A.] (Barcelona, s.n.: 1611). Peralta Francisco de, Copia de una carta que el padre Francisco de Peralta de la Compañia de Jesus, rector del colegio de los Ingleses de Sevilla, escrivio al padre Rodrigo de Cabredo [...] en que da cuenta de la dichosa muerte que tuvo en Londres la santa señora doña Luysa de Carvajal (s.l.: 1614).

Sander Elizabeth, Traslado de una carta de cierta monia inglesa llamada Isabel Sandera [...] escrita en Ruan ciudad de Francia a Francisco Englefild, Cavallero Ingles residente en Madrid, en que le da cuenta de las persecuciones, y trabajos, que a pasado por nuestra Santa Fe en Inglaterra (Sevilla, Clemente Hidalgo: n.d.).

\section{Secondary Sources}

Álvarez-Recio L., Fighting the Anti-Christ: A History of Anti-Catholicism in Tudor England (Brighton: 2011).

Borreguero Beltrànin C., "Philip of Spain: The Spider's Web of News and Information", in Dooley B. (ed.), The Dissemination of News and the Emergence of Contemporaneity in Early Modern Europe (Farnham: 2010) 23-50.

Burguillo J., "Pedro de Ribadeneyra y la inestabilidad del discurso histórico literario en torno a la empresa de Inglaterra", in Montes D. - Lillo V. - Vega M.J. (eds.), Saberes inestables: Estudios sobre expurgación y censura en la España de los siglos XVI y XVII (Madrid: 2018) 174-200.

Cairns E.C., "Crypto-Catholicism in a Protestant Land: 'La Española Inglesa”, Bulletin of the Cervantes Society of America 36, 2 (2016) 127-144.

Cano-Echevarría B., "Sidney Scribbled: The Mysterious Case of Deffensa de la Poesia", Viator 46, 2 (2015) 357-374.

Carrafiello M.L., "Robert Parsons and Equivocation, 1606-1610", Catholic Historical Review 79, 4 (1993) 671-68o. 
Cervantes Miguel de, The Exemplary Novels by Cervantes, trans. W.K. Kelly (London: William Clowes, 1881).

Chartier R. - Espejo C., Comunicación y propaganda en el Barroco. La aparición del periodismo en Europa (Madrid: 2012).

Cruickshank D.W., "Lisping and Wearing Strange Suits: English Characters on the Spanish Stage and Spanish Characters on the English Stage, 1580-168o", in Fothergill-Payne L. and P. (eds.), Parallel Lives: Spanish and English National Drama 1580-1680 (London - Toronto: 1991) 195-210.

Da Costa Fontes M., "Love as an Equalizer in La Española Inglesa", Romance Notes 16, 3 (1975) 742-748.

Díaz Noci J., "The Iberian Position in European News Networks: A Methodological Approach", in Raymond J. - Moxham N. (eds.), News Networks in Early Modern Europe (Leiden: 2016) 193-215.

Donne J. - Sypher, F.J. Pseudo-Martyr [...] A Facsimile Reproduction with an Introduction by Francis Jacques Sypher (New York: 1974).

Espejo C., "El primer periódico de la Península Ibérica: la Gazeta de Valencia (1619)", Obra Periodística 2 (2012).

Ettinghausen H., "International Relations: Spanish, Italian, French, English and German Printed Single Event Newsletters Prior to Renaudot's Gazette”, in Raymond J. Moxham N. (eds.), News Networks in Early Modern Europe (Leiden - Boston: 2016) 261-279.

Fuchs B., The Poetics of Piracy: Emulating Spain in English Literature (Philadelphia: 2013).

Hadfield A., Lying in Early Modern English Culture: From the Oath of Supremacy to the Oath of Allegiance (Oxford: 2017).

Jessopp A., One Generation of a Norfolk House: A Contribution to Elizabethan History (London: 1879).

Johnson C.B., "La Española Inglesa and the Practice of Literary Production", Viator 19 (1988) 377-416.

Keen B., "The White Legend Revisited: A Reply to Professor Hanke's 'Modest Proposal", The Hispanic American Historical Review 51, 2 (1971) 336-355.

Lake P. - Questier, M., The Trials of Margaret Clitherow: Persecution, Martyrdom and the Politics of Sanctity in Elizabethan England (London - New York: 2011).

Loomie A.J., The Spanish Elizabethans (New York: 1963).

Loomie A.J., "Francis Fowler II, English Secretary of the Spanish Embassy, 16o9-1619", Recusant History 12, 1 (1973) 70-78.

Luttikhuizen F., "Cervantes and International Affairs: A Historical Interpretation of Two Episodes in the 'Novelas ejemplares', Mediterranean Studies 15 (2006) 62-78.

Malloch A., "Father Henry Garnet's Treatise of Equivocation", Recusant History 15, 3 (1980) 387-395. 
Marín Cepeda P. (ed.), Relación de lo sucedido en la ciudad de Valladolid desde el punto del felicísimo nacimiento del príncipe Don Felipe (Burgos: 2005).

McGrath P., "The Bloody Questions Reconsidered", Recusant History 20, 3 (1991) 305-319.

Oyarbide E., "Collecting 'Toute l'Angleterre': English Books, Soft Power and Spanish Diplomacy at the Casa del Sol (1613-1622)", in Helmers H. - Cumby J. (eds.), Print and Power in Early Modern Europe (forthcoming).

Peers A.E., "Cervantes in England", Bulletin of Spanish Studies 24 (1947) 226-238.

Pollen J.H., Acts of English Martyrs Hitherto Unpublished (London: 1891).

Pollen J.H., Unpublished Documents Relating to the English Martyrs, 2 vols. (London: 1908-1919).

Ricapito J.V., Cervantes' Novelas Ejemplares: Between History and Creativity (West Lafayette: 1996).

Rico F., "Sobre la cronología de las novelas de Cervantes", in Pellistrandi B. Couderc C. (coords.), 'Por discreto y por amigo': mélanges offerts à Jean Canavaggio (Madrid: 2005) 159-165.

Roca Barea E., Imperiofobia y leyenda negra. Roma. Rusia, Estados Unidos y el Imperio Español (Madrid: 2016).

Sánchez Pérez M., "Panorámica sobre las Relaciones de sucesos en pliegos sueltos poéticos (siglo XVI)" eHumanista 21 (2012) 336-368.

Santoyo J.C., "Bibliografía tentativa de traducciones inglés-español, 1577-180o", Bells 1 (1990) 161-187.

Sowerby T., "Elizabethan Diplomatic Networks and the Spread of News", in Raymond J. - Moxham N. (eds.), News Networks in Early Modern Europe (Leiden: 2016) 305-327.

Villacañas J.L., Imperiofilia y el populismo nacional-católico (Madrid: 2019).

Warren Anderson R., "Inquisitions and Scholarship", Social Science History 39, 4 (2015) 667-702.

Williams M.E., St Alban's College Valladolid: Four Centuries of English Catholic Presence in Spain (London - New York: 1986).

Zagorin P., "The Historical Significance of Lying and Dissimulation", Social Research 63 , 3 (1996) 863-912. 